\title{
5-7. 映像のインタラクティブ化
}

\section{新谷 幹夫 (映像表現\&コンピュータグラフィックス研究委員会委員長/東邦大学)}

映像のディジタル化とともに「受信機」もコンピュータ化し，映像はコンピュータで処理されることが一つの前提になりつ つある.コンピュータの重要な特性の一つはデータを動的に処理することである．例えば，コンピュータゲームはその典型 例である．現時点では，「映像は静的だが高画質」，「ゲームは動的だが低画質」ともいえるが，CG・CV技術などの進展によ りこの差は縮まり，また，ゲームなどの対話的コンテンツも特殊技術やコストを要さずに簡単に作成できるようになると考 えられる．このような状況下，将来の映像メディアの動向として以下が考えられる．1）実写とCGの融合が進む.ゲームな どの対話的コンテンツと映像コンテンツの境界があいまいになり, 多様なレベルにおける対話的映像コンテンツが流通する.

2) 個人レベルでゲームなどを作成する人が増え，投稿サイトなどで発表・交換するようになる．3）ゲームなどの対話的コ ンテンツの芸術性が追及され，芸術の1ジャンルとして確立する.

\section{5-8. メディア工学研究の未来}

\section{吉田 俊 之(メディア工学研究委員会委員長/福井大学)}

メディア工学研究委員会が基礎をおく画像処理分野は,「新しい処理対象・処理法の創造」と「その高精度・高能率化」を 両輪として発展してきた. さて 30 年後は？両者の関係はそのままに「高次化」が進んでいる‥だろう．まず，当然ながら処 理対象の高次元化 (静止画x-yや動画x-y-tからx-y-z-tへ). 例えば，カメラは対象までの距離を含む空間情報が取得可能とな り，その表示や処理を含め，映像情報から空間情報処理へと発展しているだろう (学会名が変わっているかも). 次に，高次 数 (非線形) 化. 現状の「高精度・高能率化」は, 主として2乗誤差を微分した形の線形処理に基づくものであるが，将来，よ り適切な誤差評価法とその最小化がゆっくりと進み, 確かな数学的バックグラウンドに裏打ちされた非線形処理が少しづつ 導入されていくだろう. そして, 映像処理分野の研究者が避けて（?）きた「認識問題」を含む高次・高機能化.「何が映って いるか」を追求し，それを利用した研究が進んでいる‥だろう.

\section{5-9.パラノイヤ(偏執病)的な執念で破壊的なイノベーションを}

\author{
倉 重 光 宏 (アントレプレナー・エンジニアリング研究委員会委員長/山口県産業技術センター)
}

銀河鉄道999や鉄腕アトムなどいわゆるレトロフューチャー (懐古趣味な未来) 時代に育った者の一人として, 空飛ぶ列車 や宇宙を駆けめぐる100万馬力など未来像に対して盲信的な憧れを抱いたものだが，原子力の平和利用や宇宙開発など一部 はかなったものの，大半は空想に止まっている．10年から30年先の映像情報メディアの姿の予言は，まさにレトロフューチ ヤーを描けということであろう.アントレ研はレトロフューチャー的な先進技術は技術として見据えつつも，むしろそれら をどう実現し，どう経済的な価值獲得へ高めていくかのプロセスを扱い，今後もそうあり続けて行くことになると考えてい る. ユビキタス情報化社会や技術のグリーン化が進む中で，未来の映像情報メディアをどのように生みだし，どのように事 業化につなげていけばいいのか？妙案はないが，ただ一言言えるのは，破壊的な発想とその発想をパラノイヤ(偏執病）的 に追い求める気違いじみた執念こそがこれからも原動力であり続けるに違いない. 